\title{
CIENCIA Y SOCIEDAD
}

Volumen XXIX, Número 4

Octubre-Diciembre 2004

\section{PRODUCCIÓN DE CONOCIMIENTO Y EL DISCURSO \\ COLONIAL A TRAVÉS DE LA FOTOGRAFÍA \\ EN EL CARIBE HISPÁNICO. 1898-1940}

Karin Weyland, PhD. ${ }^{*}$

La Ciencia mecesita de aquellos/as que la desobedecen.

Theodor Adorno

Que las rosas continuan siendo lo que son. esa es la catástrofe.

Walter Benjamín

Mediante las fotografias, el mundo se transforma en una serie de particulas inconelas e independientes; y la historia, pasaday presente. en un conjunto de anécdotas y hechos diversos. La cámara atomiza. controla y opaca la realidad. ...es un simulacro de conocimiento, un simulacro de sabiduria tal como el acto de fotogratiar es un simulacro de posesión, un simulacro de violación.

Susan Sontag

\section{RESUMEN}

Este ensayo analiza la construcción del "discurso colonial" dominante en el Caribe Hispánico en base a la producción fotográfica norteamericana del siglo XIX y XX, y propone investigar si el dominio de la tecnología, en este caso la fotografía, es suficientemente poderoso para acaparar los discursos existentes, o si existen otros factores para que el discurso occidental lleve su ventaja sobre discursos altemativos de con-

* Ciencias Sociales. INTEC. 
testación, resistencia y supervivencia antillanos y latinoamericanos. De esta forma, el ensayo explora las diversas definiciones y genealogías del antillanismo y relaciona el proceso de construcción antillana con el de la construcción de la identidad nacional de los pueblos caribeños y la conformación del imperio, informados todos por un discurso occidental, positivista y colonial. Se propone también rescatar una mirada más amplia a estos temas a través de una dialéctica transnacional que reconozca la fluidez entre los procesos identitarios imperiales/coloniales, y que el discurso antillanista no se enfoque solamente en la oposición de los mismos.

\section{PALABRAS CLAVES}

antillanismo, fotografia, tecnología, identidad nacional.

\section{Introducción}

Hoy día, nos imaginamos al Caribe o a las Antillas de diversas maneras y tenemos conocimiento de esta región a través de diferentes fuentes y enfoques, sin embargo siempre han existido íconos específicos como el plátano, la playa y el ocio que, desde la época de la colonia, permanecen en el "imaginario social" del Caribe. Estos íconos culturales, que atraen turistas y curiosos, en parte apoyan un discurso (neo)colonial dominante que opaca los discursos locales subalternos, estos últimos arraigados en las luchas políticas y sociales contra el imperialismo y el (neo)colonialismo. En este ensayo analizaremos la construcción del "discurso colonial" dominante en el Caribe Hispánico en base a la producción fotográfica norteamericana del siglo XIX y XX. Y también nos preguntaremos, si el dominio de la tecnología, en este caso la fotografía, es suficientemente poderoso para acaparar los discursos existentes, o si existen otros factores para que el discurso occidental lleve su ventaja sobre discursos alternativos de contestación. resistencia y supervivencia antillanos y latinoamericanos. ¿Acaso textos clásicos como "Nuestra América" de José Martí, "Civilización y Barbarie" de Faustino Sarmiento, o "Ariel" 
de Enrique Rodó, escritos también a finales siglo XIX, no fueron suficientemente revolucionarios en la conformación de un antillanismo republicano o es que necesitamos reconceptualizar nuestra lectura de estos textos y revisar la ambivalencia occidental y el pensamiento positivista en los mismos? Por otro lado, estas preguntas, junto con un análisis del "discurso colonial" de la fotografía anglosajona del Caribe a finales del siglo XIX y comienzos del siglo XX. intentan analizar diversas definiciones y genealogías del antillanismo y relacionar el proceso de construcción antillana con el de la construcción de la identidad nacional de los pueblos caribeños y la conformación del imperio. informados todos por un discurso occidental, positivista y colonial que necesitamos analizar a través de una mirada más amplia. a través de una dialéctica transnacional que reconozca la fluidez entre los procesos identitarios imperiales/coloniales, y no se enfoque solamente en la oposición de los mismos.

\section{Hacia una historiografía fotográfica del Caribe Hispánico a partir del 1898}

Aunque todavía nos cautive mirar una fotografía y descubrir su multiplicidad de discursos y, en esa fascinación, comprendamos que cada fotografía "confiere a cada momento el carácter de un misterio" (Sontag, 1977:33), la primera representación visual del Caribe que le dio objetividad y autoridad a un discurso sobre otros fue la fotografía a finales del siglo XIX, cuando se publicaron en los Estados Unidos alrededor de 25 libros ilustrados de fotografías sobre Puerto Rico. Cuba, Hawai, otras islas del Caribe y el Pacífico, describiendo las "nuevas posesiones" norteamericanas. Así como expresa Lanny Thompson. en su crítica a esta producción fotográfica, las fotos y textos de estos libros intentaron presentar una "amplia y rica descripción de las condiciones industriales, comercia- 
les, políticas y sociales" de los nuevos territorios, frutos de la expansión norteamericana, y "captar sus posibilidades, particularmente su potencial económico y geopolítico" (Thompson, 1995).

Lejos de ser una técnica objetiva. la fotografía se utilizó como una herramienta descriptiva y documental. Ilegando a formar parte del discurso colonial de esa época, que en base a la alteridad, a la construcción del "otro". tomó auge y se asentó como el imaginario social del Caribe. superando en veracidad toda representación pictórica hasta ese momento. incluyendo las famosas litografías y dibujos de la época. Es decir, la fotografía se enfocó en la relación desigual colonial marcada por las diferencias en cultura, raza. y medios de producción y reproducción y le dio objetividad a un discurso visual sobre el Caribe. Desde la perspectiva del ojo colonizador y civilizador, como diría Edward Said, el autor del estudio clásico del "orientalismo" quién se enfocó en las representaciones europeas de Oriente y en la alteridad como una construcción histórica, resultado del conflicto imperial, las fotografías que analizaremos a continuación, dejan entrever un "Caribe imaginario" creado durante el año imperial en la historia norteamericana. es decir, el año de la Guerra Cubano-HispanoAmericana en 1898 y la anexión de Hawai. Ese mismo año culmina la lucha de la frontera territorial con México y con las poblaciones indígenas para dar paso a la conquista de la frontera ultramar, expandiendo el "Destino Manifiesto" de la ideología anglosajona a la región caribeña/latinoamericana.

De los libros publicados a finales del siglo XIX, el más impresionante y más leído fue Nuestras Islas y su Gente con más de 1,200 fotografías sobre Puerto Rico, Cuba, Hawai y las Filipinas, originalmente publicado después de haber concluido la Guerra Cubana-Hispanoamericana con texto de José de Olivares quién sirvió en la Marina y como corresponsal durante 
la Guerra, junto con fotografías de Walter Townsend, Fredrick Fout, George Dotter y otros. Igualmente, el oficial y fotógrafo George Dotty, se enroló en el Ejército para viajar a Cuba, y fue asignado a su Compañía en ese territorio en 1899, para luego pasar a ser el fotógrafo asignado de la Oficina de Ingeniería y Servicios Públicos en el distrito de la Habana donde permaneció desde 1899 hasta 1902, año de la independencia cubana. Su misión original era fotografiar los fuertes españoles pero luego esta se extendió a calles, proyectos, cementerios, y el garrote, un aparato utilizado por los españoles para matar patriotas cubanos. La intención de muchas de estas fotografías, características de la época, era documentar las prácticas inhumanas de los españoles, llevando al Caribe a un estado de pobreza y deficiencia, y por lo tanto justificar la intervención norteamericana en la región, como ente "salvador" de los nativos "pobres" y "desprotegidos". Entre los libros de esa época, también figuran el de William Dinwiddie, Puerto Rico: Sus Condiciones y Posibilidades y el de Trumbull White, Nuestras Nuevas Posesiones.

En contraste con la metrópoli "industrializada" y "civilizada", durante el final del siglo XIX, la identidad del Caribe se construyó en base a una fuerte ideología hegemónica que favorecía las nociones occidentales de racionalidad y progreso y la dicotomía occidentalista entre "civilización" y "barbarie". Esta diferenciación era articulada en reclamo de una herencia racial y civilizadora moderna que se oponía al "otro" caribeño, supuestamente "bárbaro" y "atrasado" caracterizado por los/ as indios/as, negros/as, campesinos/as, obreros/as, y mujeres nativas. La fotografía del siglo XIX describió al Caribe y a su gente como dependientes, fáciles de gobernar, con capacidad para el hábito de trabajo sin embargo sin ninguna organización eficiente, y con una cultura pasiva, posible de americanización que conformó el "discurso colonial" dominante que todavía 




Foто 1: Etnólogo Herbert Kriegger un una excavación en República Dominicana.

tenía vigencia durante la primeras décadas del siglo veinte, como veremos a continuación en las fotografías del arqueólogo y etnólogo Herbert Kriegger,

Kriegger llegó a realizar varias visitas y excavaciones en República Dominicana, Haití, Cuba, Bahamas, Puerto Rico, acompañado de su cámara, mientras trabajaba para la División de Etnología del Museo Nacional de Estados Unidos, que hoy en día es el Museo de Historia Natural del Museo Smithsoniano' (Ver Foto 1). Al igual que las Oficinas de Servicio Público, a principios del siglo XX, el Museo dependía de la Secretaría

1. Hoy dia, el Musco Nacional de Historia Natural es una institución Smithsoniana y tuve oportunidad de acceder a los archivos de Herbert Kriegger en los Archivos Nacionales del Museo de Antropologia e Historia Natural gracias a una beca del Departamento de la Iniciativa Latina de esa institución en el verano del 2000 
de Agricultura, y ya para los veinte, la Oficina de Servicio Público estaba a cargo de contratar fotógrafos del calibre de Walker Evans y Margaret Boorke-White quiénes trabajaban en los estados sureños, supervisando los proyectos sociales del gobierno durante la reconstrucción del Sur, y más tarde, uno de ellos, el húngaro-americano, Jack Delano, es trasladado a Puerto Rico para fotografiar la isla y su gente para el gobierno norteamericano.

Me gustaría que este ensayo perfile en la dirección de escribir una historiografía fotográfica del Caribe Hispánico ya que analiza la producción visual de Herbert Kriegger durante los veinte al cuarenta en Puerto Rico, Cuba y República Dominicana, utilizando como referencia la mirada imperial/colonial del gobierno de Estados Unidos en esa región a partir del 1898. Además, este ensayo intenta ofrecer nuevos parámetros para futuros trabajos que utilicen la fotografía como documentación, y así evitar caer en las mismas formulaciones del discurso occidental del proyecto europeo y norteamericano modernizador, en particular evitando caer en la racialización del "otro", que sirve como base o fundamento del discurso colonial/imperial de la modernidad, que cobra aún más vigencia a finales del siglo XIX, con la conquista de la frontera indígena-mexicana, y con los experimentos imperiales en el territorio caribeño.

Bajo una ideología hegemónica dominante, quedaba claro que el triunfo de la civilización anglosajona se lograría a través de la expansión geográfica y comercial de los Estados Unidos, y durante el siglo XIX, la nueva nación justificaba su expansión por la superioridad de sus instituciones económicas, políticas y culturales. Durante el final del siglo XIX, sin embargo, la dominación del Caribe se fundamentó en la superioridad racial, y además del discurso expansionista, se creó un discurso del "primitivo" o "no civilizado" que ya se venía 760 
perfilando con la expansión territorial por la desposesión de los grupos indígenas, y que continuó con el "otro caribeño". La articulación de la superioridad racial en el discurso colonial se logró a través de la distinción simbólica entre la civilización y la naturaleza, o lo primitivo, como veremos a continuación en la mirada colonial de finales del siglo XIX aplicada a la fotografía de Herbert Kriegger posterior a esa fecha.

\section{Reseña de la fotografía como instrumento de la metrópolis y el discurso colonial de Herbert Kriegger}

Herbert Kriegger viajó a República Dominicana durante los años veinte, treinta y cuarenta, durante la Ocupación norteamericana(1916-1924), y posteriormente, durante la Dictadura de Trujillo. Igualmente durante la Ocupación y la dictadura de Trujillo, muchos de los sectores populares de República Dominicana, como los campesinos/as, los negros/as, obreros/as y mujeres eran marginados y excluidos de proyectos de desarrollo nacional. Esta exclusión estaba sustentada en los textos de intelectuales de esa época, como Manuel Peña Batlle y Joaquín Balaguer, quiénes, a favor del régimen dictatorial y la metrópolis, intentaban imponer una ideología racial dominante en base al modelo patriarcal de hispanidad, catolicismo y superioridad racial blanca y masculina que dio pie a la Masacre del 1937 de haitianos/as y dominicanos/as. Al igual que el discurso colonial norteamericano, de finales del siglo XIX, el discurso del blanqueamiento de la raza negra y la celebración de la raza indígena como influencia principal en la construcción nacional de la identidad latinoamericana comenzaba a permearse no sólo en República Dominicana sino en América Latina entera, incluso este último discurso era parte de la construcción de algunas de las naciones Caribeñas/latinoamericanas bajo los auspicios del proyecto de modernidad y civilización, ignorando las coyunturas que se habían dado 
entre criollos, indígenas, mulatos y negros durante las luchas de independencia.

En una de sus expediciones, o "survey" como así lo escribió en el presupuesto del viaje al Secretario de Estado, Kriegger quería reconstruir "la ruta del descubrimiento de la isla" enfocándose en el primer viaje de Cristóbal Colón en las Américas, $y$ viajando por las diferentes islas caribeñas en búsqueda de similitudes y contrastes entre los habitantes, sus modos de vida, y su cultura material; este deseo de sintetizar y determinar una cultura particular a las Antillas refleja un pensamiento regionalista, sin embargo, son cuestionables las razones que motivaron este interés. En principio, Kriegger se sorprende de no encontrar más banderas de Estados Unidos flameando en las costas del Caribe. En su notas, el escribe: "El Océano caribeño, el mediterráneo americano, no es tan americano como quisiéramos creer. Prácticamente todos los puertos y la mitad de la costa sureña están bajo banderas extranjeras de nacionalidades europeas y Centro y Sur América."

Además del testimonio de sus notas y una serie de cartas y borradores de sus publicaciones, lo que más abunda en los archivos de Kriegger son las fotografías, tomadas por el mismo y por otros fotógrafos. Aparentemente, Kriegger coleccionaba postales e imágenes varias que ya para los veinte eran distribuidas y vendidas en estudios fotográficos y galerías, particularmente en Cuba donde la fotografía comenzó poco después del primer daguerre a principios del 1800's. En su artículo, "Imaginando a Cuba bajo la bandera Americana" Miguel Bretos, del Instituto Smithsoniano narra que ya para el año 1841, los fotógrafos George Washington Halsey y R.W. Holt hacían retratos de personas en sus estudios; el primer fotógrafo cubano, Manuel Arteaga, que nabía viajado a París, ofrecía daguerrotipos en el 1844, y en el año 1857, Charles Deforest Fredericks, abría una filial de su estudio neoyorquino en plena Habana. Ya 
para el 1860, había ocho estudios fotográficos o galerías en la Habana. En República Dominicana, los primeros fotógrafos, como Abelardo Rodríguez Urdaneta, Frank Adrover Mercader, Angel Villalba, Miguel Angel Sanchez Lustrino, Alfredo Senior y Ramón Molina, pioneros en el arte fotográfico de la ciudad de Santo Domingo y su país, también comenzaron aventurándose en los retratos, particularmente de las damas, y "la mirada" de ellas es el pendulum, es decir lo que llama la atención del fotógrafo y luego los lectores, como diría Roland Barthes en su libro, Cámara Lúcida. Fotos de la poetisa, narradora y pintora Delia Weber, cuya lucha logró que se legislara a favor de la mujer, muestran su pose y mirada furtiva reflejada en un espejo que ella misma sostiene, posiblemente a sugerencia del fotógrafo Alfredo Senior. Definitivamente, la época del fin de siglo y comienzo del siglo XX. el retrato y la mirada marcan el paso de la nueva tecnología.

En su libro, Visión, raza y modernidad, la antropóloga Deborah Poole explora el significado simbólico de los fotógrafos latinoamericanos que bajo una nueva moda producían retratos que en entonces se llamaban "cartas de visitas" y que curiosamente circulaban entre las familias afluentes para intercambiarse invitaciones y otras notas con sus retratos. También nos habla que a finales del siglo XIX hay una producción intensa sobre los retratos de latinoamericanos en estudios fotográficos que eran coleccionadas e intercambiadas entre las familias europeas. Lo interesante del argumento de Poole es que nos invita a pensar sobre la relación entre el colonialismo y las ideologías raciales de la época, como ella misma dice, que a diferencia de los retratos burgueses que tenían un significado representativo de la realidad, entre familiares y amigos, y por lo tanto uso fotográfico, las cartas de visitas de "nativos latinoamericanos" distribuidas entre familias europeas, eran totalmente anónimas de sujetos sin historias, lo que nos lleva a pensar que su valor solo servía como un artículo de consu- 
mo, es decir, como algo que se colecciona, que se acumula y se intercambia: este sistema de consumismo arraigado profundamente en el capitalismo mundial emergente y su dominación europea, definió la posibilidad de construir un archivo, tanto privado como público, y fijó en el público europeo las primeras imágenes y definiciones de Latino América (Poole, 1997:140).

En los archivos de Kriegger pude encontrar fotografías individuales y paneles que el mismo cortaba y armaba, pegando fotografías y texto, obviamente para demostración y explicación de sus viajes por el Caribe. A manera de colección, Kriegger organizaba estos paneles en diferentes categorías, por paisajes, costas, carreteras, construcciones, indígenas, "tipos sociales" como el había escrito, quizás haciendo alusión a los evolucionistas del siglo XVII y a la mirada o "gaze" que, junto con el concepto de raza, se utilizaron como herramientas de expansión imperial, para darle un lenguaje científico a la descripción del "otro latinoamericano" para clasificarlo y subyugarlo como tipos inferiores. Obviamente Kriegger estaba en una misión, en un "survey" (exploración), como el había escrito en sus notas, y quería reconstruir la ruta colonizadora Colón en lo que el creía ahora eran posesiones (norte)americanas. Por ejemplo, en República Dominicana, Kriegger fotografió el lugar donde yacía la primera ciudad del nuevo mundo, "La Isabela", junto con el ejército nacional dominicano en una especie de homenaje a la patria (Ver Foto 2). Fotografías de indígenas de las Guyanas Británicas que el denominó "Indios Carib", demuestra su interés por la reconstrucción del pasado y el nuevo significado de las islas caribeñas, que el extendió con sus visitas hasta América del Sur, intentando identificar la "posibilidad" o potencial de la región para implementar proyectos "americanos". La "mirada" de Kriegger también servía para informar al público norteamericano de sus descubrimientos por el Caribe; aparentemente el utilizaba las fotos que el coleccionaba para hacer réplicas de las escenas de la 


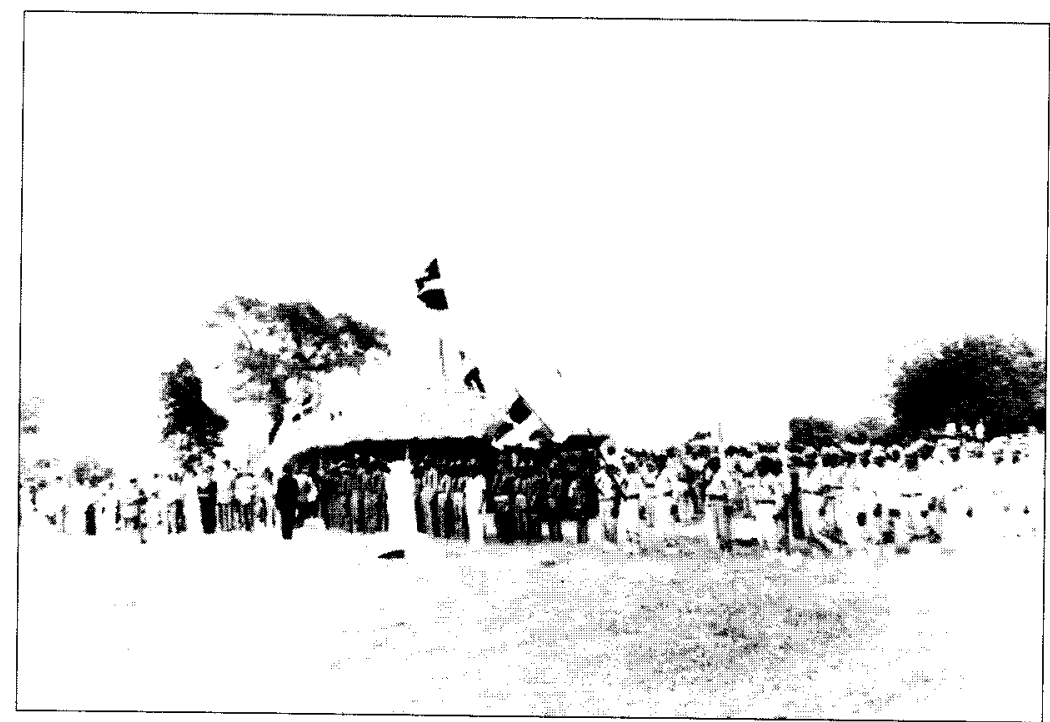

Foro 2: Ceremonia patriótica en el lugar donde se fundó la primera ciudad del nuevo mundo, "La Isabela" junto al ejército dominicano.

vida diaria de los indígenas caribeños en el Museo Nacional. Como mencioné anteriormente, Edward Said hace notar el lugar privilegiado de los antropólogos y etnólogos quienes describen y estudian las culturas de los demás, sin mencionar la "antropología del imperialismo", describiendo al "otro" como "primitivo", carente de una cultura civilizada propia, mientras su costumbre es apropiarse de los artefactos culturales encontrados que hoy en día adornan los Museos de las metrópolis. En una carta de fecha del 22 de Febrero del 1947, dirigida al Director de Montes y Minas, del Ministerio de Agricultura, de la República de Cuba, Kriegger pide permiso para visitar las aldeas indígenas que Colón menciona en su Diario para identificar las culturas y tribus de los Indios que ocuparon la isla cuando Colón la visitó. También pide permiso para llevarse consigo fragmentos de cerámica, piedra u otros objetos de origen indígena de vuelta al Museo Nacional para su posterior estudio, y aunque no lo hace notar 
en su carta, para su exhibición en el Museo. O sea que Lanny Thompson estaba en lo cierto cuando habla del interés norteamericano de conocer y dominar.

Además de las fotografías de artefactos arqueológicos e indígenas, en la colección de Kriegger se encuentran muchas fotografías de mujeres, niños y obreros quiénes aparentemente le ayudaban a Kriegger durante sus viajes, ya sea trabajando para él en sus excavaciones, hospedándolo y brindándole comida, sobre todo en República Dominicana, cerca de las cuevas del Río Chacuey, en Monte Cristi y Puerto Plata, y también en Samaná y Constanza, aparecen muchas fotografías de este tipo. Es obvia en la imágenes la relación distante que el mantenía con ellos/as ya que la mayoría aparece posando para la cámara, con

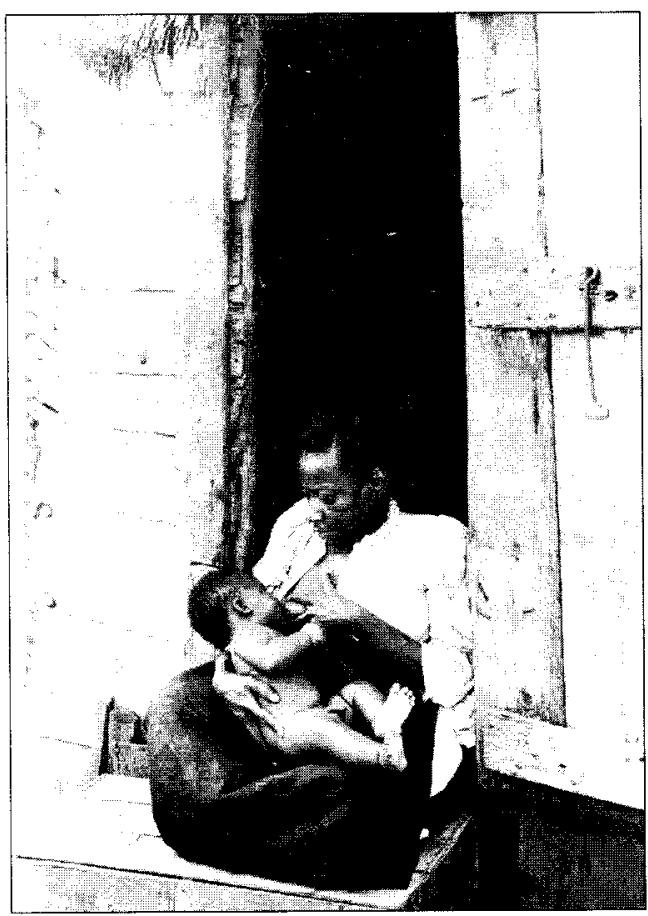

Foto 3: Mujer amamantando un niño en la puerta de su casa, San Juan Puerto Rico. aspecto solemne en el rostro y postura. Las fotos donde los sujetos se encuentran más relajados son de la familia Paewonsky de Puerto Plata con quién Kriegger compartió un viaje en barco, aparentemente en calidad de amistad.

En su libro, La construcción del otro puertorriqueño, Lanny Thompson, explica el gran número de niños y mujeres representados en los libros del siglo XIX 
y la ausencia de una clase dominante criolla, que pueda gobernar la isla, justificando las diferentes intervenciones y ocupaciones de la región por las tropas norteamericanas. La división social estaba marcada de forma muy clara por los españoles, blancos $\mathrm{y}$ ricos, por un lado, $\mathrm{y}$ los puertorriqueños, pobres y mulatos, por el otro. Entre las fotografías de Kriegger en Puerto Rico, se deja ver la imagen de una mujer negra dándole el pecho a un niño desnudo frente a una

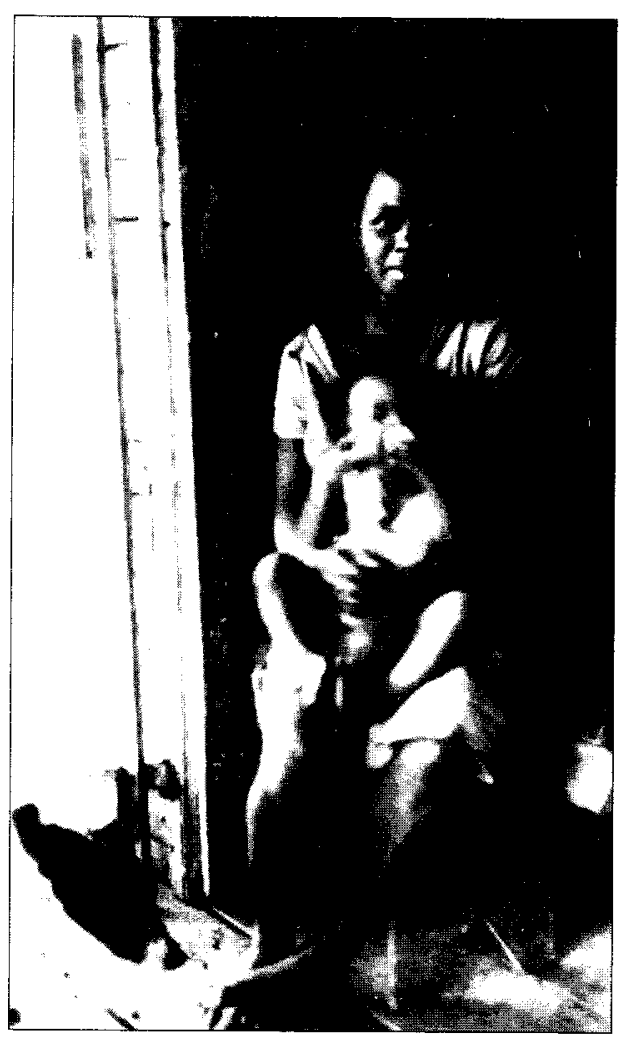

Foto 4: Cuidadora de niños en la finca de los Richetti. casa humilde de madera (Foto 3). Además de la apariencia de la ropa que ocupa buena parte de la imagen, y el estado de la vivienda de madera y paja, Kriegger recalcó el hecho que la mujer fue retratada sentada en la calle, señal de sumisión que denota el bajo status social de la misma; Kriegger escribió al borde de la foto, "En la puerta de la calle, San Juan". En República Dominicana, Kriegger hizo un retrato similar de una dominicana negra, sentada en una silla pero descalza en la entrada de una vivienda de madera que denota un aspecto humilde al anterior. Además de la ropa y la ausencia de zapatos, su estatus social bajo, también se define por su trabajo como niñera del hijo del 


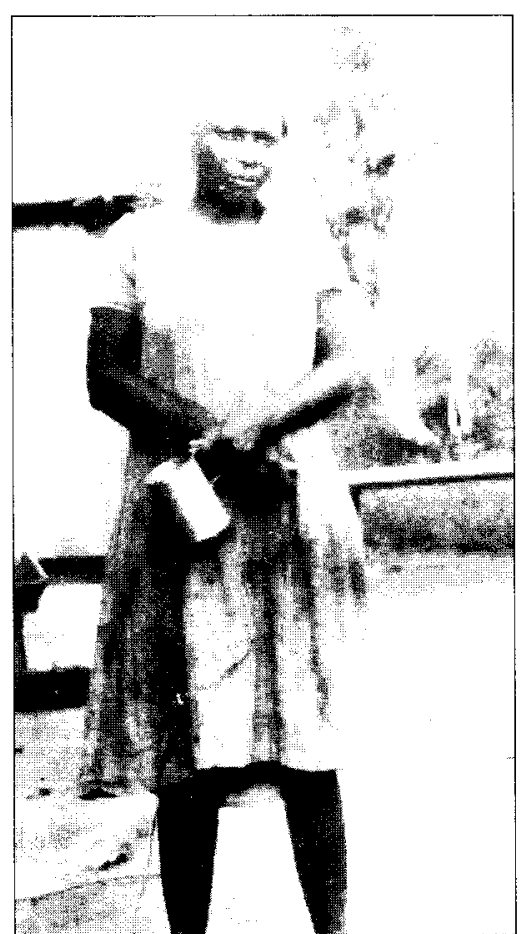

FOTO 5: Trabajadora de la familia Richetti. supuestamente encargado de la finca, el Señor Luis Richetti, donde Kriegger estaba trabajando en Samaná; Kriegger en el borde escribió "la cuidadora del hijo y esposa en la finca" (Ver Foto 4). En otras fotografías, aparecen otras dos mujeres, una como sirvienta (Ver Foto 5) y otro como niñera de los niños más grandes de la fámilia Richetti (Ver Foto 6), sin embargo jamás vemos la finca en sí, y no se especifica si los Richetti son los dueños o cuidadores de la finca quiénes aparecen en algunas fotografías, la esposa y los niños, por un lado (Ver Foto



FOTO 6: Niños de la famila Richetti y su niñera. 


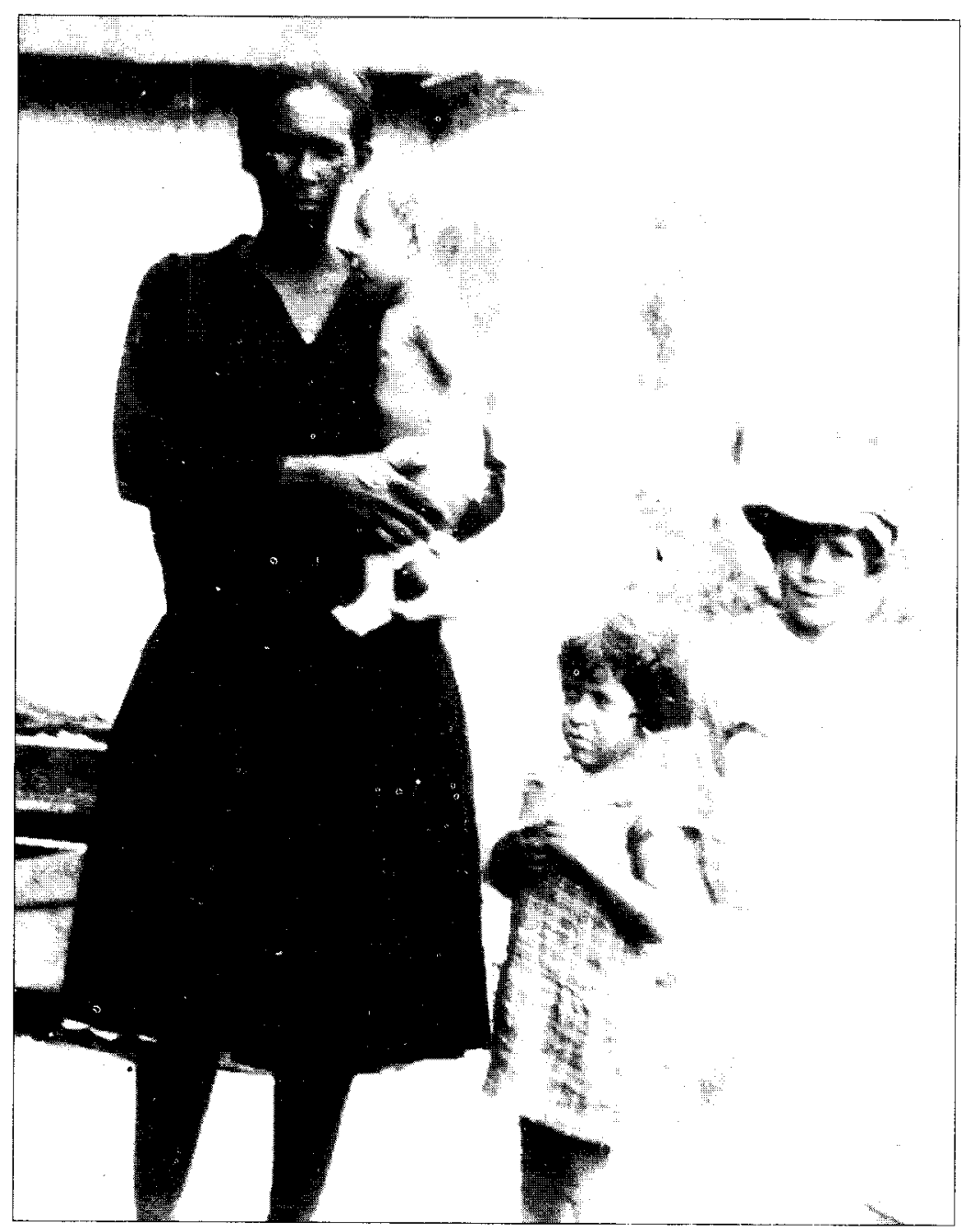

Foto 7: La señora Richetti y sus hijos.

7), y Luis Richetti por el otro, sosteniendo un rifle de caza y su presa. dos pájaros colgando boca abajo (Ver Foto 8). En su libro sobre Puerto Rico, Lanny Thompson recalca que los norteamericanos corresponsales estaban interesados mayormente en los obreros de las empresas y fincas nacionales, y no tanto en la clase dominante, evocando una necesidad de orga- 


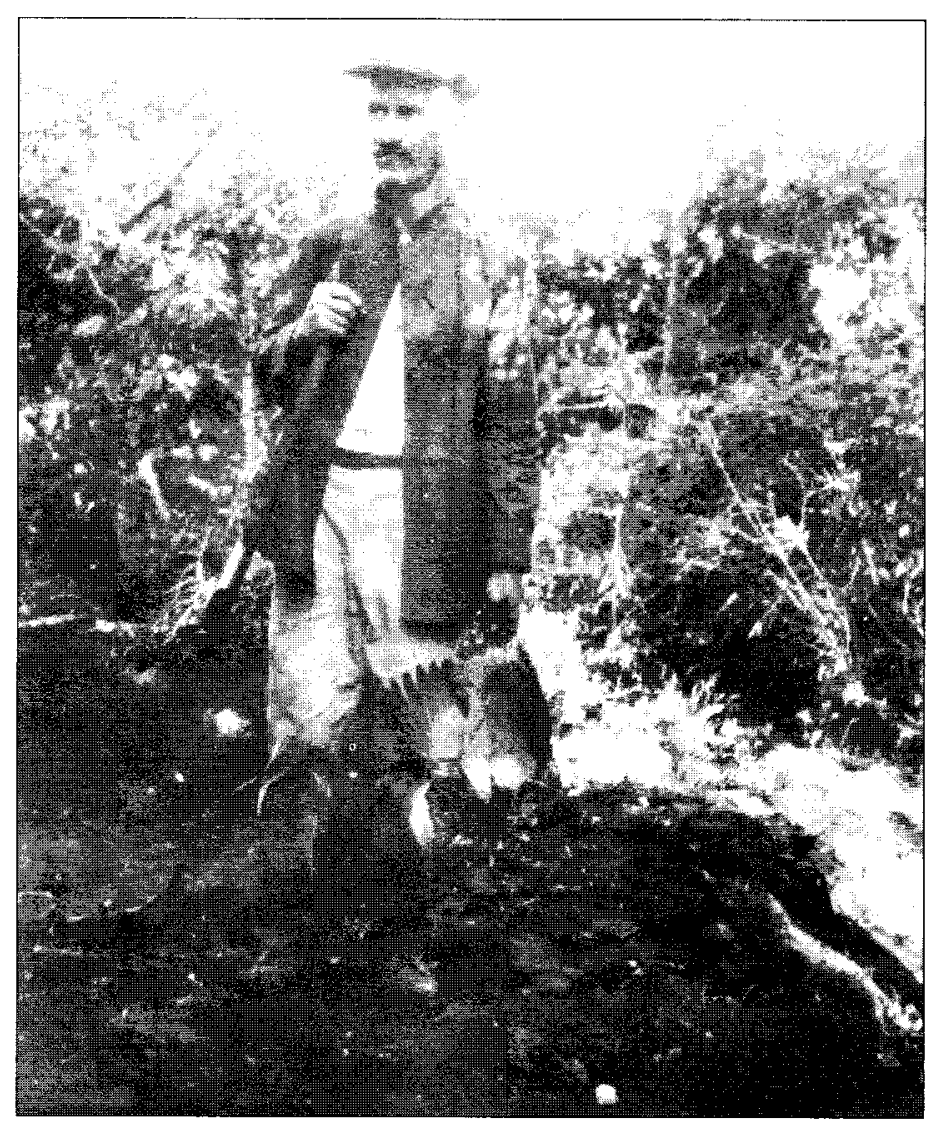

Foto 8: I.uis Richetti después de un día de caza.

nización de la administración de la producción a raíz de que los españoles y criollos no se habían ocupado eficientemente al respecto. Además del grupo de mujeres ya descritos, aparecen en las fotografías de Kriegger, un peón ensillando un buey en la finca, un señor mayor que lo ayuda en sus excavaciones y dirige un programa de radio sobre el clima y un mulato que Kriegger lo catalogó como "revolucionario" que, sin su conocimiento, utilizaba sus viajes arqueológicos como oportunidades "para regar propaganda" revolucionaria, creemos, aunque no lo especifica, en contra de la Ocupación norteamericana en 1924. 
En cuanto a la jerarquización racial, ocurre algo similar a lo ya anotado por Thompson, cuanto más bajo el nivel social de las personas, más oscura su tez, en la representación fotográfica de Kriegger. Los vestidos de la sirvienta y niñera aparecen desordenados y sucios, al igual que los cabellos, y su tez es más oscura que la de la esposa de Richetti quién es fotografiada con un vestido elegante, y su peinado estirado hacia atrás, evocando el "pelo bueno", es decir, lacio y suave, en vez de duro y seco como se le atribuye al cabello de rasgos africanos. Luis Richetti también es fotografiado con su chaqueta y rifle colgando de un hombro en señal de riqueza y autoridad, y la fotografía deja ver su color de piel más claro, y su "pelo bueno". Lanny Thompson relata que las mujeres españolas aristocráticas de Puerto Rico, eran representadas como blancas, en contraste con las puertorriqueñas mulatas y obreras; las primeras eran retratadas al interior de la casa, con libros abiertos en sus manos en señal de cultura y civilización, mientras que las mulatas y negras eran mayormente retratadas sentadas en el suelo en señal de sumisión y en grupos en la calle, o frente a sus viviendas, generalmente de origen humilde. En Nuestras islas y su gente, el texto que acompaña las fotos de las españolas lee, "las mujeres de la clase aristocrática de Puerto Rico representan la mejor y más alta civilización de España como existía hace cien años" citando a José de Olivares (Thompson, 1995: 22).

En sus viajes a República Dominicana, Kriegger retrató varias mujeres posando para la cámara, algunas de forma casual y otras en forma de montaje planificado, ya que algunas de ellas son fotografiadas sosteniendo la misma flor en la mano, inclinándose en un silla, con vestidos elegantes de cortes a la moda de la época, medias, zapatos y joyas en sus brazo y cuello (Ver Fotos 9 y 10 ). Mientras la división social/racial no es tan diferenciada como en Puerto Rico, entre las clases medias/bajas, blancas/mulatas dominicanas, si se observa una 


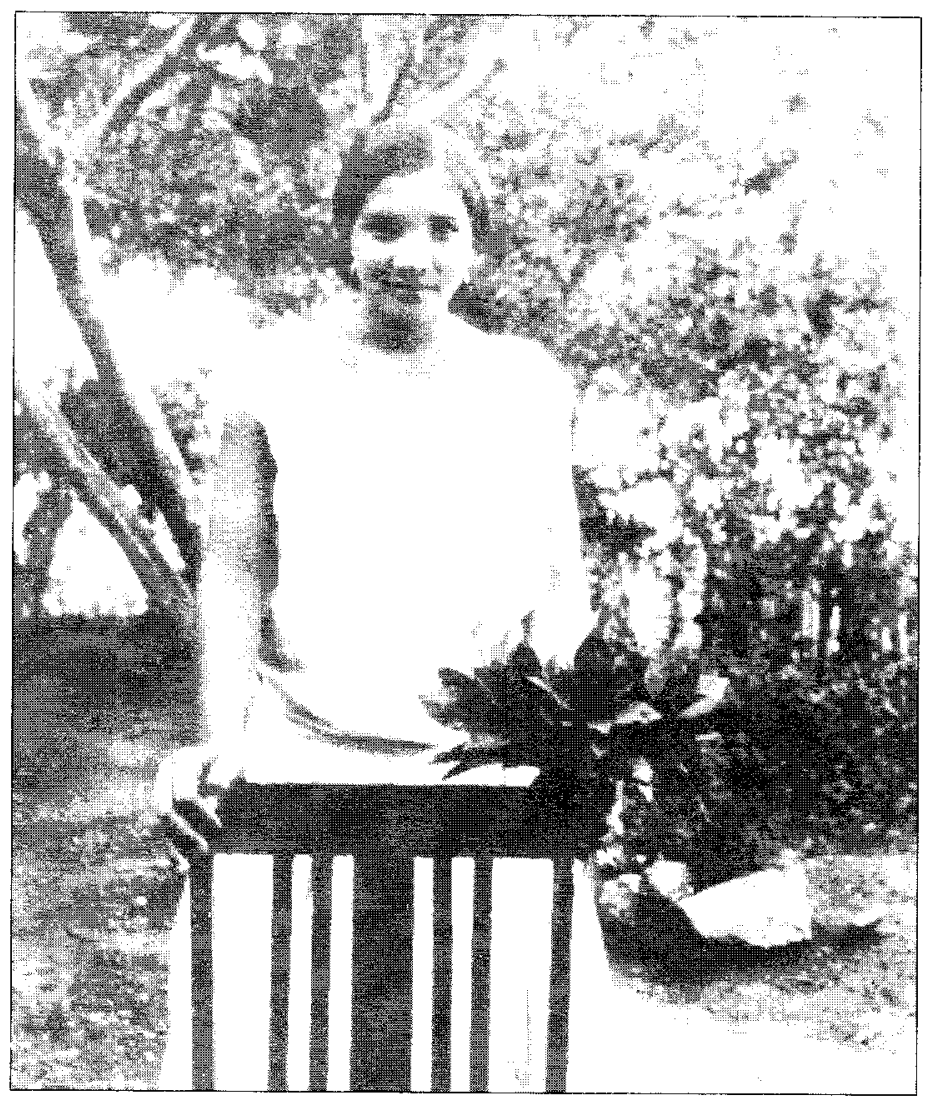

Foro 9: Tipo social: de Puerto Plata según el archivo de Kriegger.

mayor mulatización o mestizaje en las fincas del campo o establecimientos comerciales del pueblo, particularmente en la región de Puerto Plata y Monte Cristi donde se encontraba Kriegger haciendo sus excavaciones, en contraste con la clase media alta de Puerto Plata representada por la familia Paiwonsky, de origen europeo/blanco, posando para la cámara aparentemente en un barco que está por salir del puerto de Puerto Plata. La mirada colonial del siglo XIX si coincide con Kriegger, sin embargo, en retratar a la mujer como "tipos sociales" descritos por él al borde de las fotografías o como "el 




Foto 10: Tipo social: de Puerto Plata según el archivo de Kriegger.

otro exótico", es decir, "coquetas, atractivas, encantadoras y objetos de interés romántico de los fotógrafos norteamericanos", particularmente en ausencia de la presencia del hombre o figura patriarcal, implicando una conquista fácil y quizás hasta necesaria. Como dice Thompson, así como "la ausencia de una clase dominante criolla creó el espacio simbólico para la entrada de la autoridad gubernamental norteamericana", la subestimación simbólica del hombre dominicano, legitimó la transferencia de una autoridad patriarcal a otra (1995:43). Es decir, la ausencia de los hombres en los retratos de mujeres no 


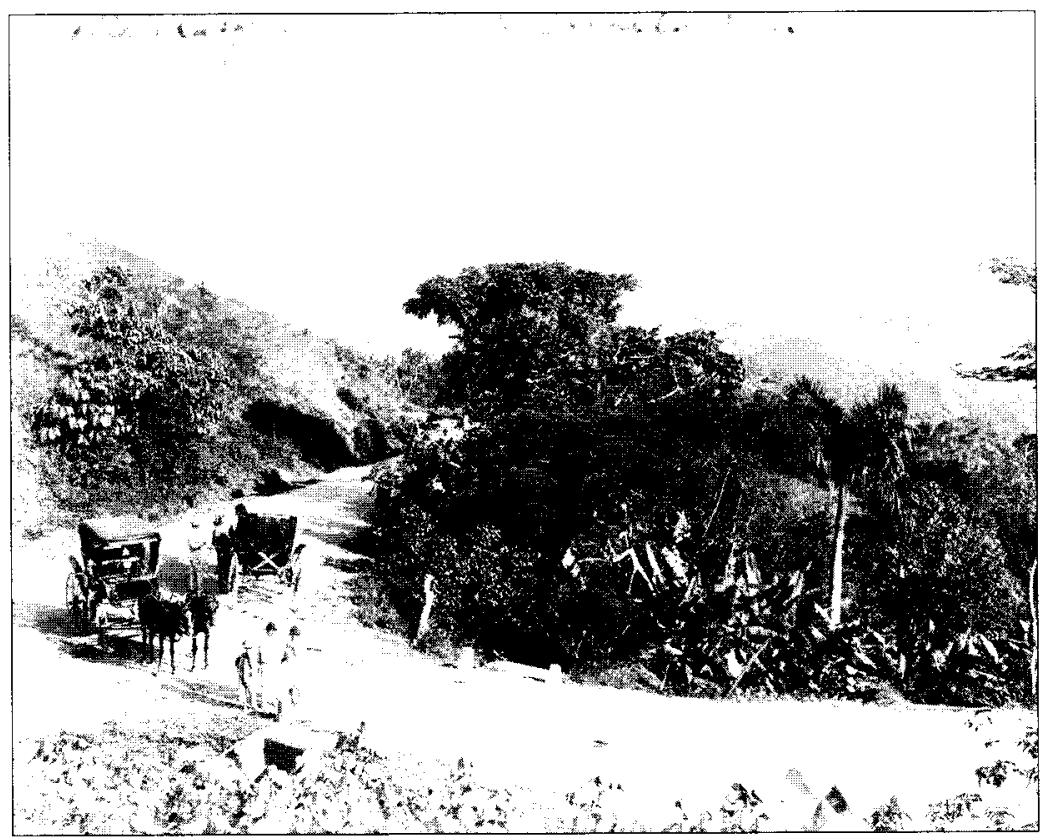

Foro 11: Carretera militar cerca de Aibonito en Puerto Rico.

solo evoca el deseo sexual del observador que acecha a su presa sino también la implantación de un nuevo sistema patriarcal en ausencia de una autoridad varonil local.

La vivienda, la ropa y las características fenotípicas sirven entonces como indicadores de la clase social de y de la racialización de la gente durante esa época. Confrontándose con el producto del mestizaje caribeno por primera vez, la raza negra y mulata parecía representar un reto para el proyecto civilizador norteamericano, al cual los fotógrafos norteamericanos, militares y corresponsales resolvieron al enfatizar las cualidades de la raza indígena, la cual era recalcada frecuentemente en categorías como "descendientes de los aborígenes" mientras que se implicaba que la raza negra estaba en extinción, a raíz del blanqueamiento de la misma y el mestizaje con la raza blanca e indígena. El éxito de la Conquista del 
territorio indígena en Norteámerica es posible que evoque esta identificación. El indigenismo, al igual que los retratos de los niños desnudos, evocaban un sentimiento de inocencia, lealtad y potencial educativo, por un lado, y dependencia y huerfandad, por el otro. La desnudez, en particular de los niños, evoca tanto la pobreza como el estado primitivo de la población, así como dice Thompson, "el niño desnudo parece como si fuera un ser natural del paraíso primitivo" (1995:41). Hay una fotografía clásica del fotógrafo Townsend agarrando a dos niños, uno en cada brazo, como apropiándose de ellos, no como sus hijos, pero como sus posesiones, dejando entrever un "imperialismo pediátrico y tutorial".

Al igual que la mirada colonial del siglo XIX, Kriegger en Puerto Rico estaba interesado en las fortalezas españolas y coleccionó varias fotografías del morro. de la Casa blanca, de una carretera militar camino hacia Aibonito, y las ruinas de una iglesia (Ver Fotos 11 y 12), en parte para enfatizar la

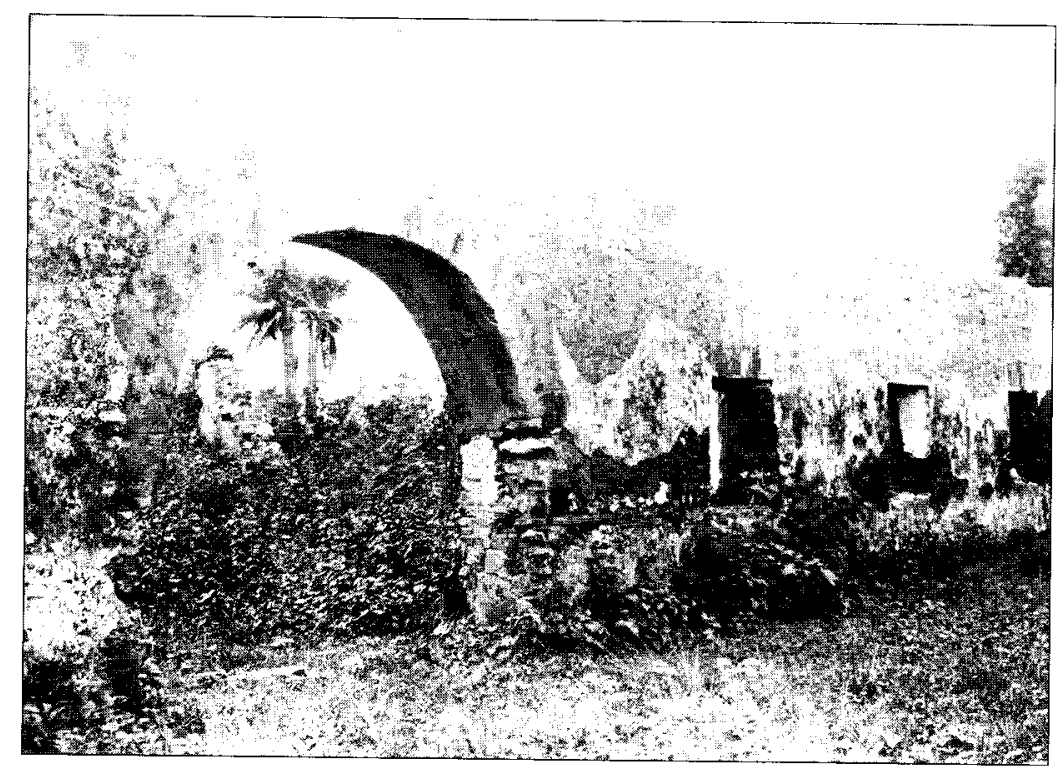

Foto 12: Ruinas de la catedral, Puerto Rico. 


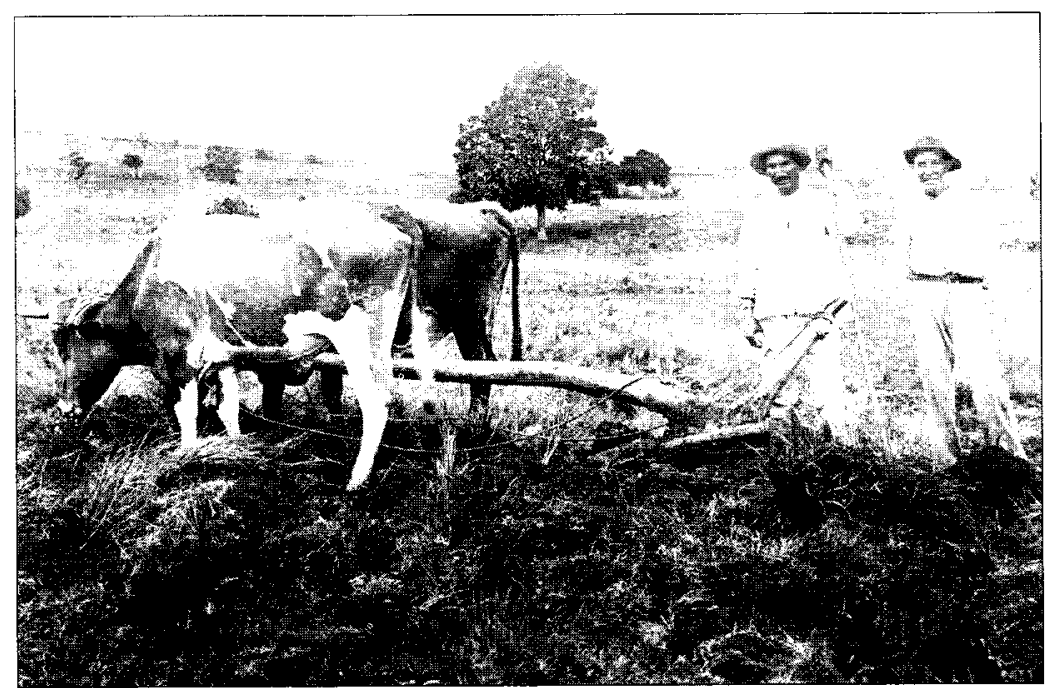

Foro 13: Campesinos cubanos trabajando la tierra.

decadencia del imperio español ya desaparecido y la gran cantidad de "posibilidades" industriales y comerciales para el beneficio del nuevo sistema norteamericano. No es coincidencia que en la década de los cuarenta se comienza a implementar en Puerto Rico el proyecto de industrialización "Manos a la Obra" que luego va a servir de modelo para implementar las políticas que hoy conocemos como neoliberales en todo Latino América. Como dijimos anteriormente, Jack Delano fue enviado de la Oficina de Servicios Públicos para retratar los cambios en la sociedad puertorriqueña, documentados en sus libros $^{2}$. Volviendo al siglo XIX, Miguel Bretos habla de la intención de la fotografía de Doty en Habana, de retratar la ciudad antes y después de la llegada de los norteamericanos, marcando los cambios positivos tanto de la arquitectura de las calles y los edificios como de la gente que habitaba en ellos.

2. Jack Delano. Pucrto Rico Mio: Four Decades of Change. Washington DC: Smithsonian Institution Press. 1990 


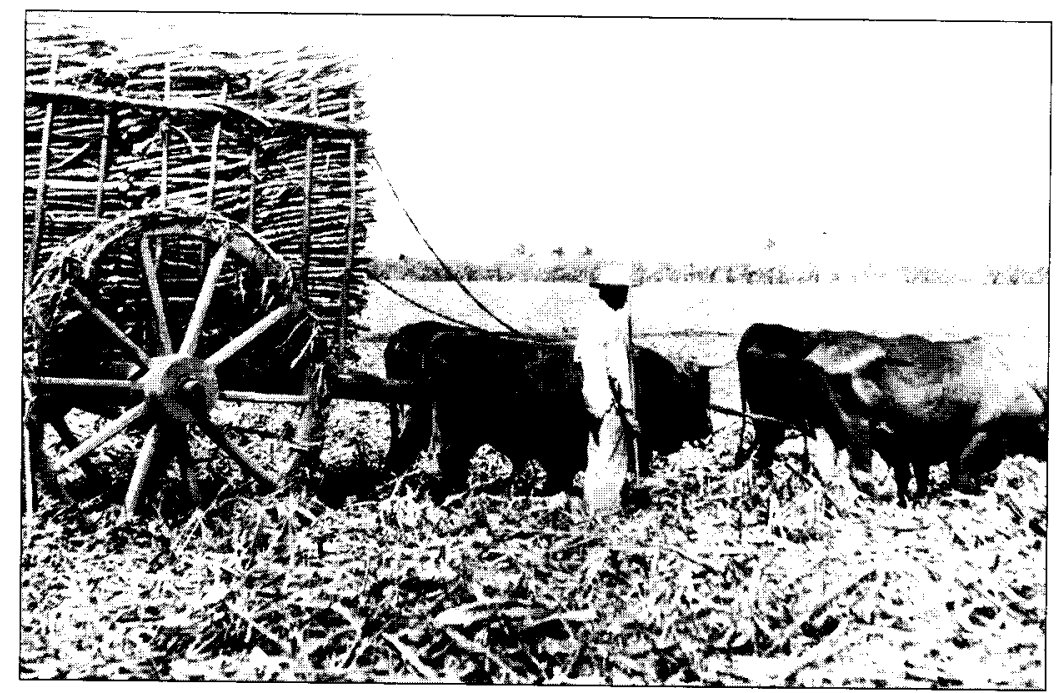

Fото 14: Trabajadores cubanos en los campos de caña de azúcar.

A pesar de su mirada distante, Doty logra penetrar algunos momentos de intimidad, y posan para su cámara, una familia campesina, algunos niños con ropa y otros descalzo, un grupo de personas durmiendo en la calle bajo el nombre de "víctimas de la represión española", una "casa pobre" de cubanos/as, un vendedor marchante en la calles de Habana, y un señor de etnicidad china durmiendo bajo un puente en Matanzas. De Cuba, Kriegger coleccionó varias imágenes de la Ciudad de la Habana y Santiago, como el capitolio, el palacio consistorial y calles importantes, al igual que postales fotográficas de trabajadores del campo, campesinos, mayormente hombres, en una plantación de tabaco, y otra de caña de azúcar, y la región del Grand Stereo, cerca de Matanzas(Ver Fotos 13 y 14). No lejos de sus precursores en la fotografía, Kriegger estaba interesado en la producción agrícola, las condiciones de transportación, carreteras y puentes, y los mercados. En República Dominicana, este interés se hace más notorio, ya que Kriegger retrata la producción agrícola del trapiche y los ingenios, los marchantes 


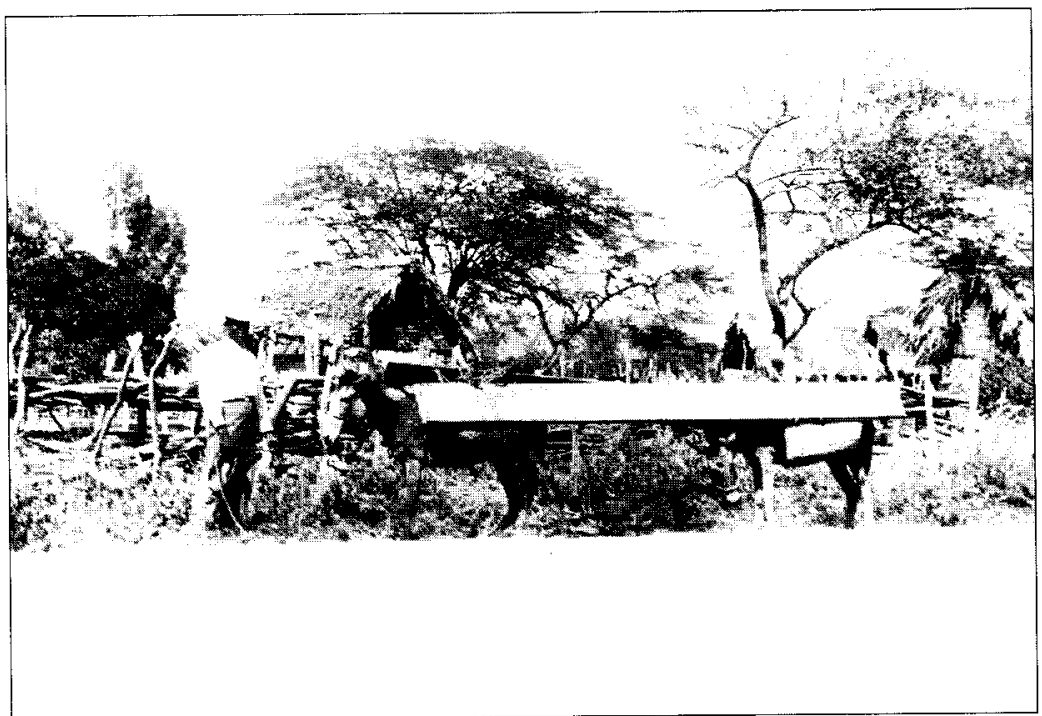

Foro 15: Sistema de transporte en República Dominicana.

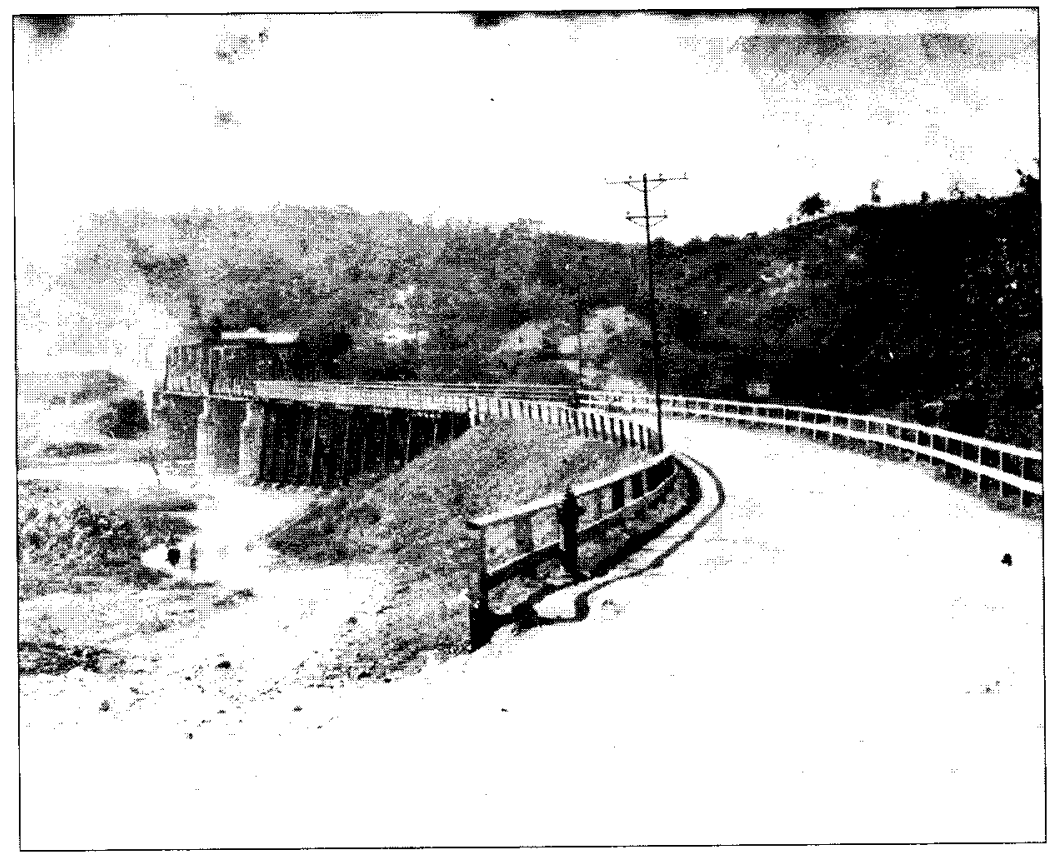

Foто 16: Puente sobre el río Yaque, Santiago, República Dominicana. 


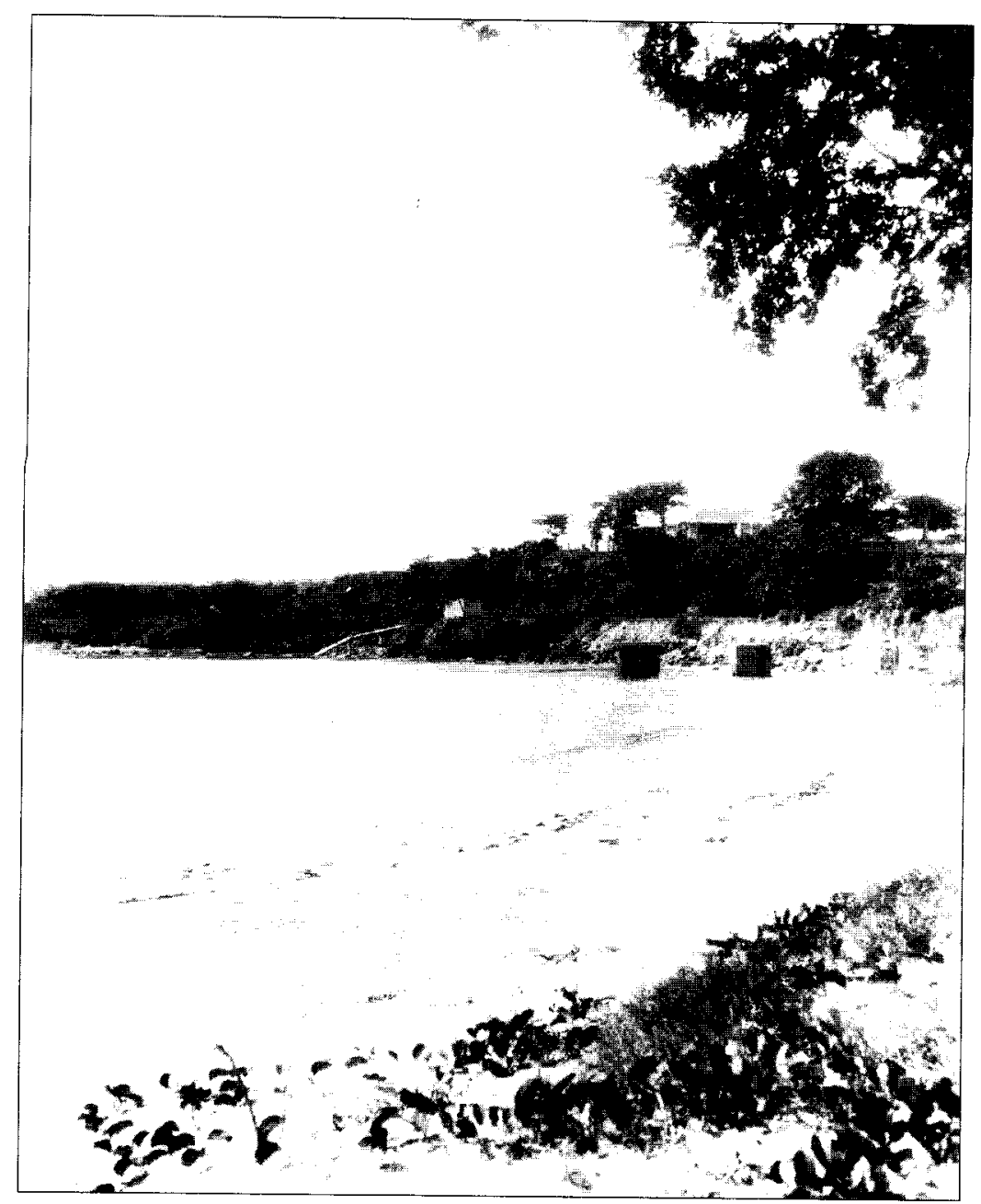

Foto 17: Playa de Sosúa.

en la Ciudad de Puerto Plata, un niño limpiabotas de Constanza, el sistema de transporte, carreteras, puentes, ríos, costas y viviendas (Ver Fotos 15, 16 y 17). Algo que recalca Thompson es la abundancia natural del paisaje y la laboriosidad de los hombres que aparecen en las imágenes, nunca como dueños de la finca o producción, sino como obreros, indicando que a 


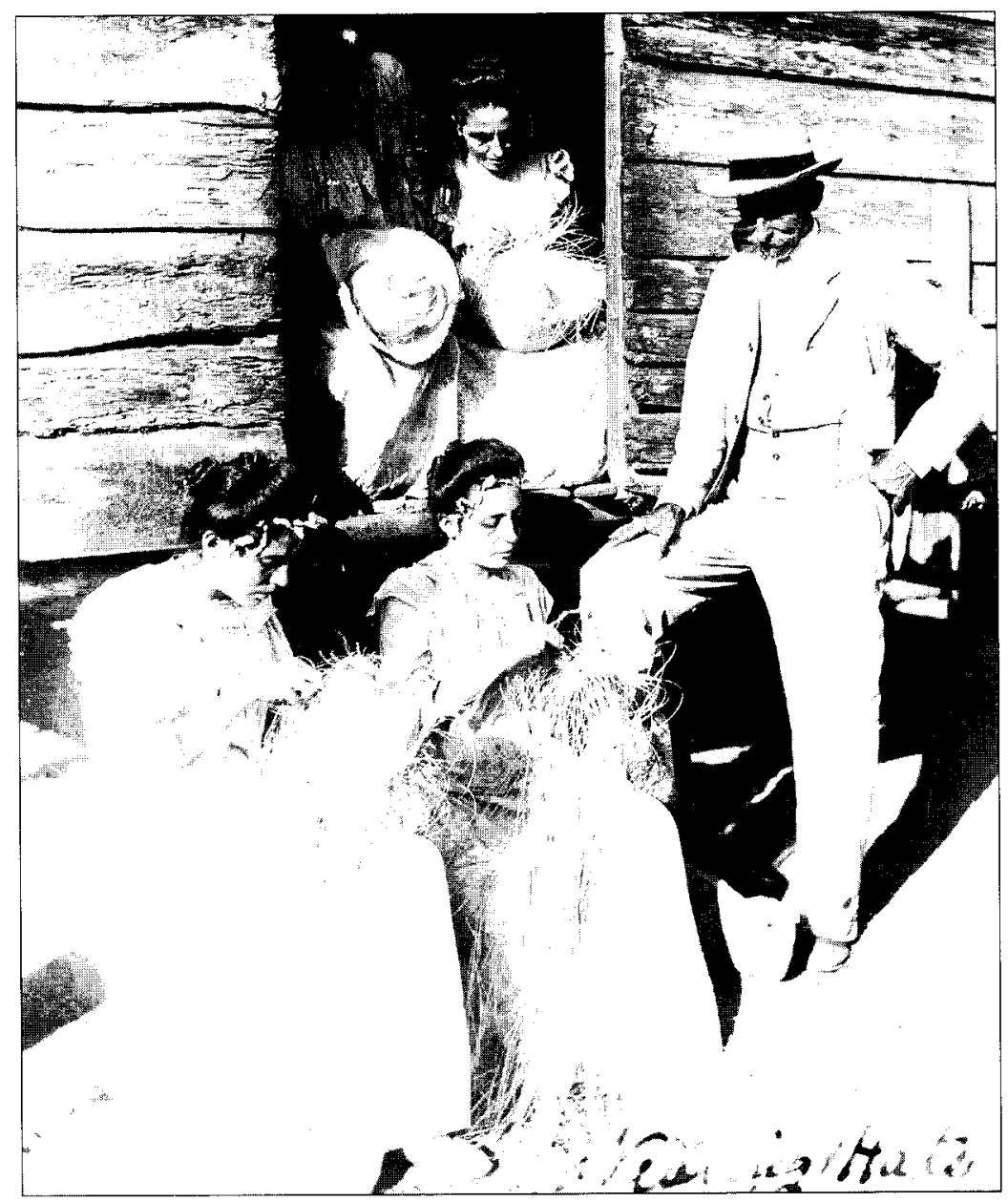

Fото 18: Mujeres de Puerto Rico tejiendo sombreros.

pesar de la mano de obra dispuesta y los frutos, aparentemente bajo el dominio español, no pudieron desarrollarse. La gran fertilidad de la tierra contrasta con la pobreza de la gente y su ociosidad, dando a entender que el gobierno español no había permitido la eficiente utilización ni de los recursos naturales ni de la gente, abriendo muchas posibilidades para el nuevo sistema norteamericano en crecimiento. 
Por lo general, las mujeres se encuentran sentadas en el piso, en señal de sumisión, cuidando niños, o trabajando alegremente, también en señal de una disciplina de trabajo. Sus trajes son sencillos como señal de conformidad y nunca aparecen en posiciones desafiantes ni de angustia. Por ejemplo, en la Foto 18, de San Juan, Puerto Rico, las mujeres posan para la cámara tejiendo sombreros con gran diligencia y destreza manual; hoy día la República Dominicana y Centro América se han convertido en una de las plataformas de exportación de manufactura textil más grande del Caribe, luego que el experimento en Puerto Rico de fábricas farmaceúticas haya resultado beneficioso. Muchos de esos productos son importados nuevamente por los gobiernos latinoamericanos, pagando sus aranceles correspondientes, para ser consumidos por la población local y sus nuevos gustos importados. Asimismo, Kriegger retrató el palacio de gobierno de Puerto Plata y Santo Domingo, y coleccionó una postal del palacio consistorial de Santiago para fines de documentar las instituciones políticas dominicanas, intención que se complementa con la documentación del ejército nacional en una de las primeras fotos del ensayo durante la celebración patria nacional del "descubrimiento de Colón". Por otro lado, hay un grupo bastante grande de personas esperando en el puerto la partida de un barco, demostrando la gran capacidad comercial ultramar de la nación dominicana. Finalmente, Kriegger retrata al Jefe de Aduanas de Puerto Plata, quién a pesar que no se le ven los ojos, nos ofrece una sonrisa complaciente en señal de sumisión. En su ensayo, "Repensar el 98" el puertorriqueño Arcadio Díaz Quiñónez narra como el cronista Stephen Crane, quién era corresponsal y cronista de guerra de Cuba y Puerto Rico, sospechaba de las sonrisas "enigmáticas" que los puertorriqueños de distintas clases sociales les dirigían a los soldados norteamericanos. A pesar que Kriegger no percibió la misma sensación de sospecha de la sonrisa dominicana, Crane 
si la entendió como "conciliadora" por un lado y "mentirosa o engañoso" por el otro. Continúa Díaz Quiñónez: "En 1898 la diferencia puertorriqueña era transfigurada por la literatura en extrañeza peligrosa, en un amenazante mundo de monstruos" (Díaz Quiñónez, 2000: 207-208).

El proyecto civilizador entonces definió su misión, no solo en cuestiones de productividad y organización o mejoramiento de la infraestructura, sino también de la americanización y gobernación de la gente y sus instituciones políticas y económicas, y quizás todavía más importante, a través de la educación y reorientación de gustos y tradiciones culturales ${ }^{3}$. De acuerdo al discurso colonial del siglo XIX que se extiende hasta mitad del siglo XX en la fotografía de Herbert Kriegger, el "otro caribeño" es un "primitivo noble en su paraíso terrenal", esperando ser cultivado y civilizado.

\section{La producción del conocimiento "antillano/ \\ latinoamericano" en dialéctica fluida con el discurso colonial/positivista a fines del siglo XIX}

Al comienzo del ensayo, planteamos la posibilidad de aclarar si el dominio de la tecnología le permitió a Estados Unidos desarrollar el discurso colonial dominante que prevaleció durante el final del siglo XIX, representado aquí en la fotografía, obviamente que la respuesta es afirmativa. A pesar que

3. En mi tesis de doctorado, "Mujeres dominicanas con un pie aquí y otro alla: Migración internacional, clase, género y cambio cultural," (New School For Social Research, 1999) explore la relación entre la transculturación de la obrera dominicana y los cambios en gustos y patrones de consumo que sirven como motivación o puente ideológico para la posterior migración masiva de mujeres dominicanas. También ver, "Dominican Women con un Pie aqui y otro allá: Transnational Practices at the Crossroads of Local/Global Agendas." en Mujeres transformando la vida, Sara Poggio, et.al (editoras). Costa Rica: Universidad Vacional, 2001. 
había una gran escasez de antropólogos u otros intelectuales locales que pudieran describir la cultura caribeña desde una perspectiva más directa e inmediata, este planteamiento nos lleva a reflexionar sobre posibles discursos alternativos de la época, recurriendo al análisis de maestros, reporteros u otros escritores de esa época, entre ellos escogí enfocarme en el ensayo, "Nuestra América" de José Martí, publicado en México y en Nueva York en 1891, por razones de espacio. Quizás también porque fue el escritor de mayor trascendencia en ese entonces, y porque hay un claro "antillanismo/latinoamericanismo" emergente en su retórica que yace entre perspectivas nacionales y transnacionales, es decir hemisféricas (Belnap y Fernández, 1998). El propio exilio de Martí lo llevó a entender la lucha independentista de Cuba desde una perspectiva transnacional, una inflexión local de un fenómeno que puede leerse a través de una dialéctica hemisférica entre la similitud y la diferencia. Sin embargo, aún ofreciendo un modelo de democracia popular, reflejado en sus palabras "con todos y para el bien de todos," en su ambivalencia y falta de concreción en cuánto a una estrategia geopolítica "nuestra", es decir de un disurso subalterno claro y preciso en cuánto a la visión política regional de las repúblicas y su interacción con el imperio como conglomerado de naciones independientes, el texto de Martí apoya ímplicitamente la visión positivista del siglo XIX, al igual que sus contrapartes intelectuales y se fundamenta en el proyecto de modernidad/colonialidad del siglo XVI.

Durante sus años en la Ciudad de Nueva York, la metrópoli que fue cuna de grandes movimientos sociales y políticos antillanos, José Martí vivió un tercio de su vida en el exilio y fundó el Partido Revolucionario Cubano. Desde allí, es decir, desde "fuera de la nación", Martí escribió muchas de sus crónicas y artículos periodísticos como crítica a la dominación imperial norteamericana sobre el resto de la región, 
y la necesidad de ésta de actuar como región, como la otra América, la América "natural y mestiza". Según Agustín LaoMontes, 2003, sin embargo, en "Nuestra América", Martí dio origen a un "manifiesto latinoamericanista contra el imperio norteamericano" con el propósito de "establecer un orden neocolonial panamericano con los Estados Unidos como potencia hegemónica" (Lao Montes, 2003). El discurso antiimperialista y anti-colonialista de Martí al parecer era una crítica al interior de las nuevas repúblicas y al exterior de las mismas, es decir a la corrupción de las clases dominantes criollas que actuaban en complicidad con la metrópoli, y hoy lo continúan haciendo, conformándose en gobiernos neoliberales periféricos. "Nuestra América" entonces se proclama como un texto "fundacional" de la identidad nacional y regional latinoamericana en oposición y en complicidad con Estados Unidos. Aún basándose en el proyecto modernista de desarrollo que articularon los intelectuales de esa época, Martí supo defender los derechos de los "nativos" de América, campesinos, mujeres, negros e indígenas, con la visión de establecer una democracia popular que le hiciera frente al colonialismo e imperialismo, y que desarrollara un conocimiento latinoamericano propio; esta idea queda clara en dos ocasiones: "la universidad europea ha de ceder a la universidad americana" y "nuestra Grecia es preferible a la Grecia que no es nuestra". Pero al estar arraigado en la corriente positivista que influyó su pensamiento, es decir, en la racionalidad y progreso, dejando de lado el etnocentrismo, el mismo Martí se demuestra ambivalente cuando describe a las masas como "incultas", "tímidas" y "perezosas" o al "criollo exótico", debilitando su retórica y proyección, las cuales se asemejan a los discursos coloniales de la época. A pesar del reclamo que Martí hace para incluir a los sujetos marginados de la historia moderna republicana, como el indio y el negro, Martí idealiza la experiencia de mestizaje, y 784 
sin abordar el tema del racismo de forma profunda, al igual que sus contemporáneos, ignora la continuidad del sistema racial, y sus clasificaciones, impuestas por la colonia, en su frase, "no hay odio de razas, porque no hay razas." El mestizaje como elemento fundamental de la construcción de la nación es problemático en cuánto promueve la idea del estado nación por encima de las diferencias raciales, idealizando una situación de mezcla de razas y culturas en cuya base se edificaría una identidad nacional homogénea, imaginada, y a la vez conflictiva para los grupos que quedarían fuera del imaginario social nacional, una herencia del proyecto de modernidad del siglo XVI.

En cuánto a la situación latinoamericana actual, si comparamos la situación político, social de las naciones latinoamericanas, arropadas por un modelo de desarrollo neoliberal globalizado que utiliza como modelo hegemónico la cultura y economía norteamericana, en complicidad con la corrupción latinoamericana, Martí sí demuestra su visión futurista en sus palabras y pensamiento cuando escribe, "si la república no abre los brazos a todos y adelanta con todos, muere la república." Quizás de forma pesimista, esta frase también se puede entender como una integración forzada a la cual Latino América, o la otra América, no puede escapar, y debe aceptar el proyecto de modernidad, civilizador que acompaña los discursos coloniales de esa época, y que hoy se han convertido en los discursos "poscoloniales" o "neocoloniales" de la globalización y el neoliberalismo. Al parecer, Martí ya se había dado cuenta de esto hace mucho tiempo atrás. América ya no puede pensar en sí misma sin el poder hegemónico de Estados Unidos; es de forma "conciliadora" que hay que "sonreír", buscando las coyunturas y las alianzas transnacionales que permitan al pueblo lograr la democracia popular que Martí anhelaba, "con todos y para todos." Asimismo, cuando Martí actúa "desde" las entrañas del monstruo de siete leguas, 
como su misma condición de sujeto transgresor lo indica, se adelanta a su época, prediciendo el pensamiento contemporáneo Latino, y las luchas políticas y sociales de Latinos/as en Estados Unidos. Habiendo vivido y trabajado como reportero diez años en la ciudad de Nueva York, Martí ya no es miembro de una América o de otra, sino de una Trans-América, una América transnacional que hoy día esta siendo trazada por las comunidades transnacionales que componen los 32 millones de Latinos/as que viven en los Estados Unidos. Para mencionar solo dos ejemplos, en las últimas elecciones políticas en Estados Unidos, siete dominicanos fueron electos a cargos políticos en sus comunidades, entre ellos una mujer, Grace Díaz, como representante del estado, o su equivalente, "diputada" del estado de Rhode Island. Las remesas de dominicanos/as a República Dominicana son la segunda fuente de divisa al país, después de la manufactura, alcanzando casi los 2,000 millones de dólares al año (Sagás y Molina, 2004).

En conclusión, me atrevo a decir que Martí, más que una "nuestra América" envisionaba una "Trans-América" que hoy día está luchando por alianzas transnacionales de comunidades indígenas, campesinas, anti-globalizantes y de movimientos de mujeres Latinas y Latinoamericanas, desde las entrañas del monstruo. Los/as Latinos/as que residen en Estados Unidos han demostrado que hay esperanza para trascender, y transgredir no sólo las viejas definiciones identitarias del "latinoamericanismo", sino también su legado de ciudadanía excluyente en base al género y la raza, expandiendo el concepto de ciudadanía dado por el estado-nación, y los "discursos hegemónicos" de la esfera pública, doméstica de Estados Unidos sobre identidad cultural y política, en los cuales el discurso de colonial del siglo XIX todavía está vigente. Ellos/as han demostrado que se puede reimaginar estas identidades y discursos en el proceso local/global al cual pertenecen, fuera y dentro del es- 
tado-nación, fuera y dentro de Estados Unidos, fuera y dentro de Latino América y las Antillas. Martí comprendió lo que es pensar, actuar y escribir desde la frontera; nuestro legado es aprender a sostenernos allí para negociar una verdadera visión transnacional de "nuestra América".

\section{Bibliografía}

Arato, Andrew \& Eike Gebhardt. The Essential Frankfurt School Reader. New York: Continuum, 1997.

Barthes, Roland. Camera Lucida: Reflections on Photography. Translated by Richard Howard. New York: The Noonday Press, 1991.

Belnap, Jeffrey and Raúl Fernández, editors. José Martí’s "Our America": From National to Hemispheric Cultural Studies. Durham and London: Duke University Press, 1998.

Bretos, Miguel. Imaging Cuba under the American Flag: Charles Edward Boty in Havana, 1899-1902 in The Journal of Decorative and Propaganda Arts, Vol. 22, pgs. 83-103.

Bryan. William (editor). Our Islands and Their People. As Seen with Camera and Pencil. Thompson Publishing Company, 1899.

Colección de Kriegger, Archivos Antropológicos Nacionales, Museo Nacional de Historia Natural, Smithsonian Institute.

Díaz Quinones, Arcadio. El arte de bregar, ensayos. San Juan: Ediciones Callejón, 2000.

Dinwiddie, William. Puerto Rico: Its Conditions and Possibilities. New York and London: Harper and Bros, 1899.

Lao-Montes, Agustín. "Martí y Rodó: la contraposición entre el modernismo y el occidentalismo," Traducción Aida Bahr. Editora Casa del Caribe, Santiago, Cuba, Del Caribe, Número 42. 2003.

Martí, José. Obras Completas. Editorial de Ciencias Sociales, La Habana, 1975 .

Poole, Deborah. Vision, Race and Modernity: A Visual Economy of the Andean Image World. New Jersey: Princeton University, 1997.

Sagás, Ernesto and Sintia Molina. Dominican Migration: Transnational 
Perspectives. Gainesville, FL: University Press of Florida, 2004.

Said, Edward. Orientalism. New York: Pantheon Books, 1978.

Cultura e imperialismo. Barcelona: Editorial Anagrama, 1993 (Traducción Nora Catelli.

Sontag, Susan. Sobre la fotografía. Traducción de Carlos Gardini, Edhasa, 1977.

Thompson, Lanny. Nuestra isla y su gente: La construcción del "otro" puertorriqueño en Our Islands and Their People. San Juan, Puerto Rico: Centro de Investigaciones Sociales, 1995.

White, Trumbull. Our New Possessions. Boston: Adams, 1898. 